\title{
Erratum to: A Womb With a Political View: Barbara Park's MA! There's Nothing to Do Here!, Prenatal Parenting, and the Battle over Personhood
}

\author{
Michelle Ann Abate
}

Published online: 18 June 2013

(C) Springer Science+Business Media New York 2013

\section{Erratum to: Children's Literature in Education DOI 10.1007/s10583-012-9195-y}

In the original version of this paper, the biography section of the author is incorrect. Now it has been corrected and the correct information is given below.

Michelle Ann Abate is an Associate Professor of Literature for Children and Young Adults at The Ohio State University. She is the author of three books of literary criticism: Bloody Murder: The Homicide Tradition in Children's Literature (Johns Hopkins University Press, 2013), Raising Your Kids Right: Children's Literature and American Political Conservatism (Rutgers University Press, 2010), Tomboys: A Literary and Cultural History (Temple University Press, 2008).

The online version of the original article can be found under doi:10.1007/s10583-012-9195-y.

\section{A. Abate $(\bowtie)$}

Literature for Children and Young Adults, The Ohio State University, 127 Arps Hall, 1945 North High Street, Columbus, OH 43210-1172, USA

e-mail: abate.30@osu.edu 